\title{
THE ANALYSIS OF THE IMPLEMENTATION OFMUNICIPAL COOPERATION AND MERGER STRATEGIES: CASE STUDY FOR SLOVENIA
}

\author{
Primoz Pevcin
}

University of Ljubljana, Slovenia, primoz.pevcin@fu.uni-lj.si

\begin{abstract}
Slovenia has only one tier of sub-national government, that is, municipalities. Currently, there are 212 municipalities, and they exhibit the same responsibilities they need to provide to their residents, regardless of their size, and these differences in size are even in the range 1:100. The new national strategy for the development of local self-government has, therefore, stressed the necessity to promote cooperation among municipalities and even potential mergers, not just to ensure cost-effectiveness but also to increase the capacity of municipalities to perform various developmental tasks. Consequently, the aim of the article is to analyse the evolution and factors driving inter-municipal cooperation and municipal mergers, where Slovenia is taken as an example, and case study approach is used in this manner. The results of the analysis indicate that territorial fragmentation at the local level has been accompanied by the increase in the inter-municipal cooperation, although some time lag can be observed. Moreover, the increase in the cooperation can be observed in particular with the onset of economic slowdown and fiscal stress emergence. The results also portray that substantial territorial rescaling cannot be expected in the near future, as suggested by the analysis of driving factors that should contribute to this process, as well as by rather weak ability of central government to promote the process. Consequently, from the practical perspective, we might expect larger role of more in-depth trans-scaling strategies as a mechanism to overcome the problem of sub-optimal size of municipalities in Slovenia.
\end{abstract}

Keywords: sub-national government; territorial fragmentation; inter-municipal cooperation; municipal mergers; Slovenia.

JEL Classification: H73, D24

\section{Introduction}

Slovenia has only one tier of subnational government, that is, municipalities. Currently, there are 212 municipalities, and their number has increased from 63 since 1994, when the last (and so far the only) local self-government reform was implemented. Interestingly, this reform mandated that all municipalities exhibit the same responsibilities they need to provide to their residents, regardless of their size, and administrative capacities and capabilities. Furthermore, if municipalities are treated with the so-called city or urban status (11 municipalities have such status), they even have some additional responsibilities, predominantly related to zoning and city development, but these are, as already noted, treated as additional responsibilities.

The problem is that differences in size amongst municipalities are even in the range $1: 100$, as the smallest municipality has just more than 300 residents, and the largest one has approximately 300,000 residents. The process of territorial fragmentation of local self-government in Slovenia has been accompanied with the lack of any strategic plans on the warranted future development of local selfgovernment. Namely, the governmental development strategy on the local self-government in Slovenia has only been adopted in late 2016, and this strategy has, amongst others, stressed the necessity to promote cooperation amongst municipalities with functional strengthening of inter-municipal cooperation, and setting up a system to promote the integration of municipalities and even their potential mergers. In essence, these intentions are targeted not just at ensuring cost-effectiveness of municipalities but also to increase the capacity of municipalities to promote local development and so 
on, as the right balance between democracy and efficiency at the local level should also be achieved (see Lavtar, Čokert 2017).

Namely, the existing studies have pointed out that the major problem of Slovenian local selfgovernment relates to dispersed and cost-ineffective implementation of tasks, which largely depends on the size of municipalities, represented by the number of residents (OECD 2011; The Court of Audit of the Republic of Slovenia 2012). Subsequently, these studies imply that there is a necessity for municipalities to combine resources in order to increase the efficiency and effectiveness of tasks implementation and service delivery for its residents, which can be done primarily through municipal cooperation and/or mergers. Therefore, the purpose of this article is to analyse the status of cooperation amongst municipalities and to portray factors that drive the cooperation and might lead to future municipal mergers in Slovenia. Specifically, the evolution of territorial fragmentation and the development of inter-municipal cooperation in Slovenia are also presented, and potential inhibitors of municipal mergers are extrapolated.

\section{Literature Review}

Municipal cooperation and mergers have been widely discussed in both theoretical and empirical literature, and they tend to be portrayed as territorial and functional rescaling in the context of local government reform processes (Schwab et al. 2017). In essence, the core of the discussions relates to the possibilities of achieving scale economies, where consolidation strategies (i.e. mergers) are put forward as a tool, and cooperation strategies only serve as an option, where mergers are either not able to be performed or the preferred institutional choice. Municipal mergers target the number, size and type of municipalities under the question (Garcea, LeSage 2005), and advocates of mergers hold that bigger should be better, cheaper, more efficient and financially viable (Dollery, Grant 2013).

Municipal amalgamations are not a new process, as they were implemented in most old industrialised countries and also recently in some post-socialist countries of Central and Eastern Europe. Actually, the first wave of municipal amalgamations was predominantly inspired with the notion that municipalities should not be too small in order to benefit from the economies of scale (De Ceuninck et al. 2010). It is worth noting that evaluations of different municipal merger processes have put forward some different reasons for the implementation of reforms, such as possible improvement of administrative and technical capacities of municipalities, rounding up of 'natural' boundaries of municipalities, alleviation of the problem of depopulation trends (see Dollery et al. 2007; Hanes, Wikström 2010). Amalgamations were particularly intensive immediately after the World War II and during the 1990s (Vojnovic 2000), and not to exclude, again during the last decade, when economic slowdown was experienced, often accompanied with increased fiscal constraints.

Similar to the mergers, the cooperation amongst municipalities, often referred to as inter-municipal cooperation, is also not a new phenomenon. A process is not just driven by the wish to achieve scale and scope economies where mergers of municipalities are not either politically or institutionally plausible but because the functioning of municipalities and their residents has become increasingly interdependent in modern globalised world (Municipal Cooperation 2014). Moreover, Bel and Warner (2016) have empirically validated the effect of additional factors, besides to scale economies, that contribute to the increase in inter-municipal cooperation, such as the existence of fiscal constraints, which should be particularly important factor for smaller municipalities; community wealth, where particularly less privileged communities should be more inclined towards cooperation; and spatial factors, where suburban localities in metropolitan areas are more inclined towards cooperation.

Similar to the history of mergers, the countries of Central and Eastern Europe are also involved into these processes, and the processes are currently driven by the growing (or at least not relaxing) fiscal constraints, increasing local public service quality requirements, and also as a way to bypass the privatisation of service provision (see, e.g. Bel et al. 2018 on the last issue). This holds predominantly for small municipalities, where limited possible competition puts limitations to the efficient privatisation, and there is also limited possibility to benefit from the reduced transaction costs associated with privatisation. 


\section{Methodology}

Municipal mergers and cooperation initiatives seem to appearing more or less sporadically on political agenda in the majority of countries, which means that they are often a continuous issue, although the magnitude of the processes and their outcomes are not the same. Subsequently, the real issue is as follows: what factors contribute to these processes? Recently, Askim et al. (2016) have proposed several factors that should contribute to municipal mergers, and these factors include fiscal stress, which forces spending cuts, and, subsequently, mergers within governmental units that enable cost reductions; urbanisation, which corresponds to the population loss in often smaller municipalities, they become unable to use scale economies in service provision; decentralisation that gives more responsibilities to local governments, which can be efficiently implemented only if appropriate size of those units is achieved; recent history of mergers that per se contributes to the new mergers as the steady-state status of the process is searched for, whereas their absence might ensure the status-quo; protection of local self-government, in particular through ratified charters, such as the European Charter of Local Self-Government (ECLSG), which strongly preserve local government independence; and the existence of consensual democracies, which prevent extensive implementation of radical reforms such as municipal mergers.

Nevertheless, the driving factors that promote inter-municipal cooperation are more economic in their nature, and they can be grouped into two major groups. The first group of factors include pressures for more efficient provision and better quality of local services, lower costs and greater administrative efficiency of municipalities, as this cooperation can be used in both urbanised and rural municipalities. The second group of factors include opportunities for municipalities to participate in a wide variety of activities and tasks, and this horizontal cooperation is heavily promoted by the European integration processes (Bolgherini 2011). Finally, if we follow the perceived reform trajectories, an increasing inter-municipal cooperation might be an indicator for the sub-optimal size of municipalities, as they tend to act as a tool to overcome predominantly economic shortcomings related to excessive territorial fragmentation (Soguel 2006), and might, under right political and institutional conditions, lead to mergers. However, the question that needs to be answered is as follows: which are those conditions?

The methodology of the article is based mainly on the qualitative approach, where the case study analysis serves as the main approach, as the existence of particular phenomenon would like to be explained, that is, given the evidence, development of inter-municipal cooperation in Slovenia. Simultaneously, the existing longitudinal data on the inter-municipal cooperation in Slovenia are presented and used, accompanied by the descriptions on the types of involvement of municipalities. This serves as one of the inputs to identify and portray factors that contribute to the inter-municipal cooperation and even their potential either positive or negative role for increased integration of municipalities.

\section{Results}

The reform of local self-government that was initiated in 1994 leads to increasing territorial fragmentation at the local level in Slovenia, as the number of municipalities has since then increased from 63 to 212. This transformation was implemented predominantly on the voluntary basis, as the reform was inspired by the possible improvements in local democracy (see, e.g. Čokert 2005). The end result of the reform was that many new rather small municipalities, in terms of population size, have emerged, as now more than one half of municipalities have less than 5,000 residents (Statistical Office of the Republic of Slovenia 2016), which is actually legally prescribed minimum size of the municipality. This indicates that exceptions have become the rule.

Interestingly, the dynamics of the process indicates that there was an initial boom, as immediately after the law on the reform was installed, the number of municipalities has risen to 147 , as the only basic criterion for the establishment was the expressed will of the residents of certain locality. Furthermore, from the number in 1998, additional 45 municipalities were established, their total number increased to 192. Only then, the central government started to put additional criteria on the establishment of additional municipalities, and this has somehow slowed down the process. Namely, since then only 
one new additional municipality was established in 2002 , and because of the slightly relaxed criteria in 2005, additional 17 new municipalities were established in 2006, when the total number increased to 210 (see Bačlija 2007). After 2006, only 2 new municipalities were established, 1 in 2011 and 1 in 2014, which indicates that the process of additional territorial fragmentation of the country at the local level has terminated, at least for now.

Interestingly, the increased territorial fragmentation of the country and the establishment of new municipalities have somehow contributed to the increased magnitude of inter-municipal cooperation, although it might be argued that a substantial time lag can be observed (see Table 1). Namely, if we scrutinise the existing data, before 1997, there was no inter-municipal cooperation observed in Slovenia. In 1997, legal prescriptions mandated that municipalities cannot outsource the delivery of their tasks to other municipalities, which was one of the common practices till then, but this did not substantially foster the inter-municipal cooperation, as till 2004 only two joint municipal administration bodies were established, which represents a common and an excepted statutory arrangement for inter-municipal cooperation in Slovenia.

Nevertheless, after 2004, the trend of increasing inter-municipal cooperation can be observed; since 2006, 10 additional joint municipal administrative bodies were established, encompassing 39 municipalities (Napast 2009). However, the expansion of joint activities and cooperation amongst municipalities was observed after 2007, and the final outcome of this process is that in 2017, 52 such bodies exist, and 202 municipalities participate in at least one of such body (see Ministry of Public Administration 2018). This increase in the amount of cooperation practically overlaps with the onset of economic downturn, which was in the case of Slovenia accompanied with substantial fiscal stress.

Interestingly, these 202 municipalities participating in the inter-municipal cooperation activities encompass approximately $60 \%$ of the residents of the country, which supports the evidence that predominantly smaller municipalities are involved in these activities, whereas larger municipalities do not perceive the need to be involved into these activities. Furthermore, the practical evidence suggests that the major factors driving these cooperation initiatives relate to possible achievement of financial economies, ability to implement certain additional tasks, scarcity of human resources and demand for increased labour efficiency. The existing evidence portrays that the majority of these joint municipal administrative bodies are performing tasks related to municipal constabulary and inspection activities, Information and communication technologies and accounting services, public procurement and legal affairs (Ministry of Public Administration, 2018), whereas there is a limited focus on the cooperation for the provision of economic and social local public services or ensuring local economic development activities.

Table 1. The dynamics of territorial fragmentation and inter-municipal cooperation in Slovenia, 19942017(Sources: Ministry of Public Administration 2018; Bačlija 2007; author's compilation)

\begin{tabular}{|c|c|c|}
\hline Years & $\begin{array}{c}\text { Number of } \\
\text { municipalities }\end{array}$ & $\begin{array}{c}\text { Number of joint municipal } \\
\text { administration bodies }\end{array}$ \\
\hline 1994 & 63 & - \\
\hline 1995 & 147 & - \\
\hline 1998 & 192 & 2 \\
\hline 2003 & 193 & 12 \\
\hline 2006 & 210 & 37 \\
\hline 2008 & 210 & 45 \\
\hline 2011 & 211 & 52 \\
\hline 2017 & 212 & \\
\hline
\end{tabular}

As the above presented evidence portrays, during the past 2.5 decades, Slovenian local selfgovernment experienced increased territorial fragmentation that was a direct result of 1994 local selfgovernment reform, which stressed predominantly local democracy issues. However, the search for cost-effectiveness in municipal functioning, combined with increased fiscal stressed, have contributed, although with certain time lag, to the rise in inter-municipal cooperation, although this cooperation has 
rather limited magnitude. Nevertheless, the vast evidence on territorial rescaling occurring in other European countries and limited inter-municipal cooperation have contributed to the necessity to implement structural reforms of local self-government, and this idea has also started to be politically promoted by government through the aforementioned developmental strategy.

The major problem is a very diverse size of Slovenian municipalities and the fact that legal provisions currently allow only voluntary municipal mergers. Subsequently, the way to ensure scale economies, cost-effectiveness and operating capacities of predominantly small municipalities is by pursuing transscaling strategies in the form of inter-municipal cooperation, which represents the alternative to both rescaling strategies as well as to the privatisation of service delivery and task implementation. Subsequently, inter-municipal cooperation represents the so-called soft mechanism to overcome the issue of the too small size of municipalities because it allows functional optimisation without interfering in the territorial and political status of municipalities, which is often more politically plausible and even possible (Steen et al. 2017).

The following question remains: what are the future prospects for implementing hard mechanisms to overcome the issue of the sub-optimal size of municipalities? The statement is put differently as follows: are there any actual prospects to implement major, that is, radical and structural reforms of local self-government in Slovenia, involving hard mechanisms such as municipal mergers? The starting point to this question is the governmental developmental strategy on local self-government in Slovenia (Lavtar, Čokert 2017), which perceives only voluntary mergers of municipalities, even if they admit in the strategy that there is excessive fragmentation of territory and irrational organisation of municipalities. Consequently, if no top-down approach in fostering municipal mergers is expected to occur, the analysis should at least portray possibilities of voluntary mergers, and the most suitable option is to inspect the drivers for the reform, following the above-described outline (methodology) developed by Askim et al. (2016).

Specifically, the current status of factors that should drive municipal mergers in Slovenia reflects that the existence of fiscal stress might be the only major driver for the reforms and also this factor is losing ground because of the recent economic recovery. Other factors, such as urbanisation, decentralisation and the recent history of municipal mergers, do not seem to be in favour of mergers in this particular context, as country is still highly fiscally centralised, urbanisation change rate is rather low, and, practically, there is no recent history of mergers. Furthermore, ECLSG has been fully ratified in Slovenia, and any non-voluntary status change in municipalities is not allowed even by constitutional arrangements. Besides, the existing political system is strongly based on the consensual decision making, as proportional voting system prevails at both central and local level.

Therefore, if we follow Soguel's (2006) framework, political grouping of municipalities in the form of mergers, or at least municipal agglomerations, cannot be expected. These might also be concluded by elaboration of Franzke et al. (2016), who stated that the problem of sub-optimal municipal size and excessive territorial fragmentation that demands municipal mergers can be solved only if the central government has the ability to provide effective administrative structures at the local level. In the case of Slovenia, this ability is rather limited not just by the insufficient effect of drivers but also by existing legal and constitutional arrangements.

In contrast, government can also effectively promote inter-municipal cooperation by promoting institutional development of these initiatives, for example, in the form of municipal associations, which are able to efficiently manage developmental projects and complex technical tasks as well as local public services. As the evidence portrays, municipalities in Slovenia have so far used intermunicipal cooperation with the purpose to jointly deliver mainly tasks related to inspection and constabulary activities, which suggests that they have focused only on those activities that were due to the reform process transferred to them afterwards.

This might imply some reluctance to use inter-municipal cooperation more extensively; the evidence is further promoted by the lack of involvement of larger municipalities. The reason might predominantly be due to the fact that during the socialist socio-economic regime, municipalities tended to be often forcefully merged, and the arrival of democratisation boosted the realisation of the basic principles of local self-government. The evidence portrays, at least in the case of Slovenia, that this has led to the 
formation of many very small municipalities, and the cooperation initiatives have only gained ground when fiscal constraints emerged.

Nevertheless, we can clearly identify factors driving inter-municipal cooperation in Slovenia. As already noted, predominantly smaller and less-privileged municipalities tend to be involved into such activities, meaning that not just fiscal stress and scale economies are driving the process but also wealth and spatial factors - the trend that we can observe is that cities are not so inclined towards that process yet smaller municipalities surrounding municipalities are much more inclined, needless to say that they are also economically less privileged. To finalise, we could classify the factors contributing to the cooperation in Slovenia in this manner, that the process is mainly driven by fiscal stress persistence but necessarily accompanied by considerations of scale economies assurance as well as by specific wealth and spatial factors of municipalities.

\section{Conclusions}

This article analyses the evolution of territorial fragmentation and inter-municipal cooperation in Slovenia. The results of the analysis indicate that territorial fragmentation at the local level has been accompanied by the increase in the inter-municipal cooperation, although some time lag can be observed, and the increase in the cooperation can be observed in particular with the onset of economic slowdown and fiscal stress emergence. The results also portray that substantial territorial rescaling cannot be expected in the near future, as suggested by the analysis of driving factors that should contribute to this process, as well as by rather weak ability of central government to promote the process.

Consequently, from the practical perspective, we might expect larger role of more in-depth transscaling strategies as a mechanism to overcome the problem of sub-optimal size of municipalities in Slovenia. Namely, if we scrutinise specific context and potential for municipal mergers in Slovenia, it can be observed that the current status of driving factors mainly acts as an inhibitor to the mergers, which can explain the practical lack of such initiatives. The policy proposal, therefore, is to scrutinise more thoroughly these factors, in order to ensure and enable mergers in the future, that would enable overcoming the problem of sub-optimal size of municipalities also with the so-called hard mechanisms.

\section{Acknowledgement}

The author acknowledges the financial support from the Slovenian Research Agency (research core funding No. P5-0093).

\section{References}

Askim, J., Klausen, J.E., Vabo, S.I. \& Bjurstrøm K. (2016). What Causes Municipal Amalgamation Reform? Rational Explanations Meet Western European Experiences, 2004-13. In Local Public Sector Reforms in Times of Crisis - National Trajectories and International Comparisons. Houndmills: Palgrave Macmillan, 59-80.

Bačlija, I. (2007). Analizanastajanjanovihobčin in prvihlokalnihvolitev v tehobčinah. Lexlocalis, (5), 47-64.

Bel, G., Hebdon, R. \& Warner, M. (2018). Beyond privatisation and cost savings: alternatives for local government reform. Local Government Studies.[Accessed 20.03.2018]. Available from Internet: http://www.tandfonline.com/

Bel, G. \& Warner, M. (2016). Factors Explaining Inter-municipal Cooperation in Service Delivery: A MetaRegression Analysis. Journal of Economic Policy Reform, (16), 91-115.

Bolgherini, S. (2011). Local Government and Inter-Municipal Cooperation in Italy and Germany. PIFO PolitischeItalien-Forschung. Occasional Papers, no. 12/2011.Gießen: InstitutfürPolitikwissenschaft, JustusLiebig-UniversitätGießen.

Čokert, A. (2005). Teritorialni del reformelokalnesamouprave v Sloveniji. Dela, (24), 207-217. 
De Ceuninck, K., Reynaert, H., Steyvers, K. \& Valcke, T. (2010). Municipal Amalgamations in the Low Countries: Same Problems, Different Solutions. Local Government Studies, (36), 803-822.

Dollery, B., Byrnes, J. \& Crase, L. (2007). Is bigger better? Local government amalgamation and the South Australian rising to the challenge inquiry. Economic Analysis \& Policy, (37), 1-14.

Dollery, B. \& Grant, B. (2013). Symposium on Amalgamation and Financial Sustainability in Local Government: Part 1. Public Finance and Management, (13), 53-57.

Franzke, J., Klimovsky, D. \& Pinterič, U. (2016). Does Inter-Municipal Cooperation Lead to Territorial Consolidation? A Comparative Analysis of Selected European Cases. In Local Public Sector Reforms in Times of Crisis - National Trajectories and International Comparisons. Houndmills: Palgrave Macmillan, 81-98.

Garcea, J. \& LeSage, E.C. (2005). Municipal Reform in Canada: Reconfiguration, Re-Empowerment and Rebalancing. Toronto: Oxford University Press.

Hanes, N. \& Wikström, M. (2010). Amalgamation impacts on local growth: are voluntary municipal amalgamations more efficient than compulsory amalgamations?.Canadian Journal of Regional Science, (33), $57-70$.

Lavtar, R. \& Čokert, A. (2017).The Development Strategy on Local Self-Government in the Republic of Slovenia up to 2020. Ljubljana: Government of the Republic of Slovenia.

Ministry of Public Administration (2018). Skupneobčinskeuprave. [Accessed 15.02.2018]. Available from Internet: http://www.mju.gov.si/

Municipal Cooperation (2014).Inter-municipal cooperation. [Accessed 20.01.2018]. Available from Internet: http://www.municipal-cooperation.org/

Napast, S. (2009).Skupneobčinskeupraveobčinodprvihzačetkov do danes. In Zbornik II. Posveta, Delovanjeskupnihobčinskihuprav v Sloveniji, 6-9.

OECD (2011).OECD Territorial Reviews: Slovenia 2011. Paris: OECD.

Schwab, C., Bouckaert, G. \& Kuhlmann, S. (2017). Autonomy, Performance, Participation: Lessons from the Comparative Study of Local Public Sector Reforms. In The Future of Local Government in Europe. BadenBaden: Nomos, 11-22.

Soguel, N.C. (2006). The inter-municipal cooperation in Switzerland and the trend towards amalgamation. Urban Public Economic Review, (6), 169-188.

Statistical Office of the Republic of Slovenia(2016).SI-Stat Data Portal.[Accessed 23.12.2016]. Available from Internet: http://www.stat.si/

Steen, T., Teles, F. \& Torsteinsen, H. (2017). Improving Local Service Delivery: Increasing Performance through Reforms. In The Future of Local Government in Europe. Baden-Baden: Nomos, 53-77.

Vojnovic, I. (2000). The transitional impacts of municipal consolidations. Journal of Urban Affairs, (22), $385-$ 417.

The Court of Audit of the Republic of Slovenia (2012).Audit Report on the Regulation of the Field of Municipalities. Ljubljana: Court of Audit of the RS. 